\title{
БОРИС АНТОНЕНКО-ДАВИДОВИЧ ЯК БОРЕЦЬ ЗА КУЛЬТУРУ УКРАЇНСЬКОЇ МОВИ
}

Карікова Н. М. Борис Антоненко-Давидович як борець за культуру української мови.

Оглядова стаття присвячена дослідженню творчого шляху українського письменника і перекладача Б. Антоненка-Давидовича. Особливу увагу приділено його мовознавчим працям, в яких ідеться про культуру української мови в др. пол. XX ст.

Ключові слова: Б. Антоненко-Давидович, культура мови, українська літературна мова, класична традиція, жива народна мова.

Карикова Н. Н. Борис Антоненко-Давидович как борец за культуру украинского языка.

Обзорная статья посвящена исследованию творческого пути украинского писателя и переводчика Б. Антоненко-Давидовича. Особое внимание уделено его языковедческим работам о культуре украинского языка во второй половине ХХ в.

Ключевые слова: Б. Антоненко-Давидович, культура речи, украинский литературный язык, классическая традиция, живая народная речь.

Karikova N. M. Borys Antonenko-Davydovych as the fighter for the standardization of the Ukrainian language.

A survey article dealing with the life work of the Ukrainian writer and translator B. Antonenko-Davydovych. Special attention is paid to his linguistic publications on matters relating to proper Ukrainian usage from the second half of the 20-th century.

Key words: B. Antonenko-Davydovych, proper usage, Standard Ukrainian, classical tradition, living language of the people.

Дослідники життя та діяльності українського письменника i перекладача Бориса Дмитровича Антоненка-Давидовича (1899-1984рр.) 
зазвичай розділяють його творчий шлях на два періоди: перший окреслено 1923-1935 рр. (від появи на сторінках київського журналу «Нова громада» його дебютного оповідання «Останні два» і до публікації останньої перед засланням збірки «Паротяг ч. 273»); другий - 19571984 pр. (від повернення реабілітованого в 1956 р. письменника до літературного процесу і до останніх днів його життя) [19, с. 33]. Між цими двома періодами - двадцять два «мертві», або втрачені, для творчості митця роки, два десятки з яких він відбув на східносибірській каторзі в тюрмі й концтаборі.

Життєвому та творчому шляхові Б. Антоненка-Давидовича присвячено чимало наукових розвідок (І. Дзюба, Д. Чуб, Л. Бойко, Б. Тимошенко та ін.), газетних публікацій (В. Іванисенко, В. Гриневич), спеціальних літературознавчих досліджень (нещодавно О.Хамедова оборонила дисертацію «Б. Антоненко-Давидович: доля, творчість, критична рецепція» [34]) і т. ін. Головну увагу дослідників привертає насамперед літературна спадщина майстра слова, де центральне місце посідають такі відомі оповідання, повісті й романи письменника, як: «Туктук ...» (1926 р.), «Синя Волошка» (1927 р.), «Смерть» (1928 р.), «Печатка» (1930 р.), «За ширмою» (1957 р.), «Слово матері» (1960 р.), «Семен Іванович Пальоха» (1965 р.) та ін. Наприкінці XX - на поч. XXI ст. починається період активного вивчення Б. Антоненка-Давидовича як мовної особистості. Так, у 1993 р. Г. Вишневська опублікувала статтю «Питання української мови у творчій спадщині Б. Антоненка-Давидовича» [10]. Упродовж 2007-2009 pp. 3-під пера Л. Касян вийшло щонайменше чотири розвідки на зазначену тему $[15 ; 16 ; 17 ; 18]$. Окрім того, мова письменника стала предметом наукових досліджень О. Божко, О. Божук, О. Карчевської $[6 ; 7 ; 14]$ та ін. I все ж таки мовознавчий аспект творчості письменника залишається на сьогодні маловивченим. У нашій розвідці ми спробуємо проаналізувати студії Б. Антоненка-Давидовича, присвячені проблемам культури української мови, закцентувавши свою увагу на впливові нормалізаторів 20-х pp. ХX ст. на мовознавчі погляди письменника.

Перші його статті про мову побачили світ на початку 1960-х років у тогочасній періодичній пресі (журнали «Жовтень», «Дніпро», газета «Літературна Україна»). Згодом ті статті склали «чудовий» мовний посібник під назвою «Як ми говоримо» [8, с. 39]. Що ж змусило Б. Антоненка-Давидовича почати писати про культуру української мови? Відповідь на це питання знаходимо в його листі до Н. Суровцевої: «Я ... взявся за мовознавчі справи лиш тому, що, «из дальних странствий 
возвратясь» 1957 року до Києва, я побачив у періодиці та книжках, не кажучи про живе мовлення, такий хаос, що мене аж смуток охопив», - i далі: «Чудова мова на очах перетворювалася на таку макароністичну суміш, що ніби досі нічого не робилося, щоб якось упорядкувати іiі, ніби не було вельми корисних праць Олени Курило, Синявського, Гладкого, Сулими та багатьох інших, що їх поглинула невблаганна Лета часів лихоліття» [33, с. 5]. Щоб якось протидіяти «нашим мовознавцям» [повоєнної доби], які, за словами письменника, «не робили того, що належало», проте «часом виробляли таке, що тільки дискредитувало нашу літературну мову, відривало iiі від народного кореня, зате наближало до братньої російської мови», Б. Антоненко-Давидович, як він пише, «взявся чистити ті авгієві стайні, нічого, власне, не вигадуючи нового, а лиш нагадуючи призабуте й додаючи до нього дещо 3 того, до чого сам дійшов своїми роздумами над нашою мовою та гарячим бажанням зберегти iї красу та оригінальність» [33, с. 5].

60-ті pp. ХХ ст. називають добою «культурного ренесансу» в Україні, характерною рисою якої стало «звернення до спадщини 20-х рр., намагання повернути викреслені імена, опублікувати твори письменників Розстріляного Відродження» [23, с. 18]. Саме в цей період Б. АнтоненкоДавидович виступає 3 різкою критикою мовної політики 30-40-х рр., що викликає «великий суспільний резонанс» [23, с. 18]. На III Пленумі правління СПУ (1960р.) він висловив цілковиту незгоду щодо пункту Закону про освіту, де йшлося про добровільність у виборі російської чи української мови навчання, адже це, на думку митця, загрожувало розвиткові української культури в цілому [16, с. 198]. Для талановитої патріотично налаштованої молоді шістдесятих років постать письменника стає «знаковою» [23, с. 18].

Аналіз мовознавчих праць Б. Антоненка-Давидовича варто розпочати 3 розвідки «На сторожі слова», що іiі було вміщено в збірнику його статей «Про що і як» (1962р.). У зазначеній праці автор проаналізував мову чотирьох «молодих у нашій літературі» українських письменників: В. Бабляка (взявши для аналізу його книжку «3 пісень життя»), П. Гуріненка («Червона скеля»), М. Стояна («Земля і люди») та С. Плачинди («Кам’яна веселка»). На початку розвідки дослідник зазначив, що «мова цих книжок, незважаючи на окремі хиби й огріхи, загалом справляє приємне враження своєю барвистістю, образністю та лексичною різноманітністю ...» [2, с. 101]. Далі ж автор розвідки запропонував «більш-менш докладно» розглянути ті випадки, коли молоді письменники відходять «від 
мовних традицій класики й живої народної мови», спускають 3 ока «потребу пильнувати за працею свого «знаряддя виробництва» [2, с. 104]. Найбільше занепокоєння автор статті висловив із приводу того, що молоді письменники зловживають деякими словами, тоді як про слова-синоніми вони забувають або ж навіть «скасовують» їхнє використання [2, с. 104]. Наприклад, мова названих письменників рясніє словами «казати», «тільки», «попасти(сь)», «трапитись», «зараз», «обов'язково», «всякий» та ін., а от лексеми, що їх можна використати в тих самих синтаксичних конструкціях і в тому самому лексичному значенні, як-от: «говорити», «лише», «потрапити», «статись», «тепер», «неодмінно» (або «конче», «доконче», «доконечне»), «різний» та ін., трапляються в їхній мові лише спорадично, через що ці «нещасливі» мовні одиниці 3 часом потрапляють до групи, за словами Б. Антоненка-Давидовича, «занедбаних чи майже невживаних» слів [2, с. 104-108]. Іще автор статті наводить приклади використання слів у невластивому їм значенні, як-от: зажити («Рани мої зажили») зам. «відомого всім слова «загоїтися»« [2, с. 111-112]; рімати, рішення («Раптом приймає рішення $і$ гукає ...») зам. ухвалювати, ухвала, постанова [2, с. 114]; знаходитися («Не знала, де знаходиться Волгоград») зам. поправного «Не знала, де Волгоград» [2, с. 116]; вірний, вірно («Дрімлюга знайшов вірний илях») зам. Правдивий [2, с. 118]; лоб («Чистий дівочий лоб») зам. чоло [2, с. 121122]; зараз («У нас зараз весна») зам. mеnер [2, с. 116] і т. ін. Б. Антоненко-Давидович наголошує, що така поширена практика «загрожує певним розривом» між живою українською мовою і мовою художньої літератури [2, с. 104]. Головну причину хибного вживання слів він убачає в зміні «ставлення письменника до мови, якою він пише ...» [2, с. 108-109]. I «якщо наші попередники, - зауважує автор розвідки, - вдавалися ... до народних джерел і ними живилися, то ми воліємо нашвидку перехоплювати потрібні нам слова й вислови 3 сучасних літературних і газетних джерел, мова яких далеко не завжди насичена живою образністю й барвистістю» [2, с. 108-109].

Показово, що при визначенні нормативності тих чи тих форм Б. Антоненко-Давидович послуговувався критерієм поширеності мовного явища в творах письменників-класиків, а також критерієм народної мови, або етнографічним критерієм*. За ілюстрацію цього можуть правити такі цитати: «Спробуймо пошукати відповіді в нашій класиці та мовній народній практиці» [2, с. 121] або: «Наведемо приклади 3 класики й народної мови ...» [2, с. 107], або ще: «В живій народній мові 
й класичних зразках ...» [2, с. 114] та ін. Уживаючи слово «класика», Б. Антоненко-Давидович мав на увазі мову таких відомих письменників, як I. Котляревський, Т. Шевченко, Леся Українка, Марко Вовчок, I. Нечуй-Левицький, Г. Барвінок, Ю. Федькович.

У розвідці «Тонни і грам» (1962р.) Б. Антоненко-Давидович, якого під ту пору тогочасні критики і рецензенти почали називати «тонким знавцем» української мови, а мову його творів відзначати як «багату», «образну» та «барвисту», згадує свої перші непевні кроки в літературі [4, с. 128]. Що привертає особливу увагу в названій статті, то це самокритичний погляд письменника на мову власних творів раннього періоду. Перші його оповідання, написані, за словами Б. Антоненка-Давидовича, «кучерявою мовою», «серйозна критика» забракувала, закинувши їх авторові «бідність» мови [4, с. 138]. Він згадує: «Мені бракувало сталого мовного підгрунтя, і я не раз пік рака перед редакторами, бачачи, якого строкатого вигляду набирають сторінки мого рукопису після їхнього правлення ...» [4, с. 143]. Щоб виправити таке непевне становище, він «заходився вивчати мову класиків, виписуючи кожне характерне слово, кожний цікавий вислів» [4, с. 144]. «Моїми настільними книжками, - згадує автор статті, - стали словник Грінченка й збірка приказок та прислів'їв Номиса» [4, с. 144]. Не забував він і про «живу» українську мову, що засвідчує така його цитата: «Я ... ніколи не розлучався 3 олівцем і записником, куди записував усе, що тільки траплялося почути нового 3 живих уст народу» $[4$, с. 144$]$. Підсумовуючи сказане, дослідник побажав молодим письменникам якнайшвидше дійти до «незаперечної аксіоми: мову, якою ти пишеш, треба знати досконало» [4, с. 155].

У 1964 році письменник оприлюднив другий збірник критичних статей «В літературі й коло літератури», в якому знайшлося місце для двох нових розвідок на тему мовної культури. Одна 3 них, під назвою «Про те ж саме», присвячена мові «книжок для молодшого та середнього шкільного віку, що їх видало останнім часом Державне видавництво дитячої літератури УРСР» [3, с. 194]. Нагадавши всім добре відому істину про те, що «людина засвоює мову ще 3 колиски», Б. Антоненко-Давидович наголошує: «... але удосконалює ії в дитячому садку, в середній та вищій школі» [3, с. 194]. Поставивши на меті «лише звернути загальну увагу на те, що суперечить традиціям нашої класики та живої мови народу, а заразом змусити читача замислитись над словом, над слушністю вживання його в тому чи іншому контексті», автор статті обрав для аналізу мови творчість восьми українських 
письменників (розглянувши лише по одному їхньому твору): Л. Ляшенка， Ю. Збанацького， О. Бердника， В. Владка， Б. Харчука, П. Ребра, В. Кочевського та I. Сенченка [3, с. 198]. Б. АнтоненкоДавидович виокремив «спільні огріхи», найтиповішими серед них є такі:

1. Невідповідне контекстові вживання деяких слів, наприклад: «Радісно бачити щзастя тих, хто не знав раніше навіть простої посмішки» (Владко) замість усмішки, бо, як зазначає автор статті, «усміхається людина, коли їй радісно, приємно, хороше на душі...; посміхаються ж люди - 3 жалю, з іронії чи коли хочуть покепкувати 3 когось» [3, с. 202]. Інший приклад: «одяг [дід] окуляри» зам. «надів [дід] окуляри», бо, як пояснює Б. Антоненко-Давидович, «одягати можна одяг, або одежу, - сорочку, спідницю, пальто ..., такі ж речі, як шапку, хустку, а тим більше окуляри - в нас надівають, а не одягають ...» [3, с. 203] та ін.

2. Ненормативне використання активних дієприкметників на -чий, -иий, -щчий, як-от: «знаюча людина», «згасаючий погляд», «активізуючий препарат», «палаюче ... жаром обличчя» та ін. За словами Б. Антоненка-Давидовича, «не злидні чи недорозвиненість української мови спричиняють ці хибні речення 3 активними дієприкметниками, яких не подибуємо в живій мові народу, а мала обізнаність деяких наших письменників з тим добром, що лежить у них під боком» [3, с. 195, 212].

Наведене твердження автора статті цілком віддзеркалює позицію більшості українських мовознавців 20-х років ХX ст. щодо неприпустимості вживання в літературній мові активних дієприкметників на -чий, -иий, а також пасивних на -мий. Наприклад, О. Курило в 1925 р. писала: «Українська мова не знає активних дієприкметників на -чиц̆, -(в)щий, ані пасивних на -мий у тому творенні та в тій функції, як їх уживає сучасна українська літературна мова, як ото: - Тварини, жиючі й живші на землі. Факт, спостерігаємий ... Незадовольняючі наслідки. ... Далекосягаюча спеціалізація та ін.» [22, с.9]. М. Сулима називав активні дієприкметники на -чий (на кшталт «всеохоплююче узагальнення») «антинародними», пояснюючи їх широке вживання в українській мові впливом російської мови [30, с. 74-75]. Аналогічні думки висловлювали й О. Синявський [25, с. 95], і М. Перегінець [24, с. 129] та ін.

3. Незразкове вживання орудного дійової особи. Автор статті наголошує, що «ні в класичній нашій літературі, ні в живій мові дійова особа не стоїть в орудному відмінку, а звичайно - в називному» 
[3, с. 195, 214]. Письменник уважає це за «особливість українського синтаксису, яку навряд чи $є$ потреба ламати» [3, с. 195, 214].

Цілком очевидно, що подібні твердження Б. АнтоненкаДавидовича грунтуються на працях мовознавців 20-х років (Є. Тимченко, О. Курило (раннього періоду), М. Сулима, В. Сімович, С. Смеречинський, М. Новицький та ін). Так, у 1920 р. О. Курило писала: «Такі особові пасивні звороти [на кшталт Головну увагу було звернуто мною або Це вже подано ним до відома] (тобто такі, що в них $є$ дієва особа), що ними так рясніє російська літературна мова, неприродні для української мови», - і далі: «українська мова дуже любить пасивні звороти, але неособові, такі, що в них немає дієвої особи» [21, с. 17]. В. Сімович вислови на кшталт Мною написано книжкку називав «барбаризмами» [26, с. 282-283], бо, за словами вченого, «ні народня складня, ні давніщі народні письменники [клясики] не знають» таких конструкцій [27, с. 18]. За М. Сулимою, «при дієслівних формах-присудках на -но, -то у народній українській фразі не буває (це - закон) орудника діяльника» [31, с. 79]. Аналогічну думку висловлювали і М. Гладкий $[11$, с. 63], і С. Смеречинський [28, c. 16-17].

4. Використання орудного присудкового, як-от: «Він був нечутним, невидимим». На думку Б. Антоненка-Давидовича, природніше вживати називний відмінок іменника, що $є$ частиною складеного присудка, на зразок: «Це була дуже гарна спеціальність». Письменник зауважує: «Кажуть, що ці обидві форми паралельні, але я не знаю, чи $є$ доцільність у цьому паралелізмі», - i далі: «Мені здається, що треба усталювати мову, зводячи до мінімуму всякі паралелізми, за якими часто криється звичайнісінька мовна неохайність та недбалість» [3, с. 195, 216].

Підставою для такого твердження Б. Антоненка-Давидовича стали знову ж таки мовознавчі рекомендації нормалізаторів 20-х років XX ст. Наприклад, М.Сулима вважав використання називного присудкового «найкардинальнішою рисою української народньо-масової мови» [32, с. 267]. Схожу думку висловлював і М. Гладкий, який в оперті на позицію $\mathrm{C}$. Тимченка писав: «Вельми поширений у нас i орудний відмінок в іменних реченнях с [sic!] дієсловом «бути», навіть коли віддаємо стан або прикмету, що справедливо вважається за полонізм» [11, с. 62]. Приставав на думку колег і С. Смеречинський, який зазначав: «... при всіх формах дієслова бути, в усіх позиціях і без жодних відтінків значення, українська народня мова знає, як норму, лише присудкового 
називного, а поруч із ним у певних випадках прийменникові та ін. конструкції. Орудний тут не властивий; буває здебільшого через чужі впливи (хоч і в архаїзмах своїх)» [28, с. 87].

5. Неправильне вживання прийменникових конструкцій. «Людина, що знає українську мову, - пише Б. Антоненко-Давидович, - не скаже: «глечик для молока», «пляшка для олї», «мішок для пшениці». Так чому ж наші дитячі письменники пишуть: «щара для одежі» (Збанацький), «це торбина для книг» (Харчук), а не - шафа на одежу, торбина на книжки?» [3, c. 195, 221].

У висновку Б. Антоненко-Давидович наголошує, що «у літературі для дітей ми - не тільки письменники, а й учителі», тому «наша творчість усіма сторонами, в тому числі й щодо мови» повинна відповідати «своєму високому призначенню» [3, с. 226].

У статті «Краса рідної мови» (1964р.) Б. Антоненко-Давидович зачіпає питання мовної культури українських учителів. Він пише: «Мене вражає лексична убогість, коли вчителеві бракує слів на щонайпоширеніші в шкільній практиці поняття, i він навмання бере перше-ліпше російське слово або перекрутить українське слово так, що воно не лізе ні в український тин, ні в російські ворота» [1, с. 235]. «Створюється враження, - веде далі письменник, - що вчителеві байдуже, як він говорить тією мовою, яку викладає, яка є рідною мовою і для нього, і для більшості учнів: аби якось сказати!.» [1, с. 235]. Завершується розвідка невтішними словами автора про те, що «при такому ставленні до рідної мови нема чого й згадувати про ії красу: краса тут, як кажуть у народі, i близько не ночувала» [1, с. 236].

У 1970 році виходить друком його книжка «Як ми говоримо», що набула широкого розголосу не тільки на території Україні, а й за ії межами (як відомо, схвальні рецензії на цю працю, крім української преси, з'явилися ще в російському фаховому журналі «Вопросы литературы» (№ 5 за 1971 р.), а також у варшавському науковому часописі «Slavia Orientalis» (ч. 1 за 1972 р.). Перше ж видання книжки стало бестселером, а згодом вона «зажила доброї слави у читачів України та західної діаспори (двічі була перевидана - у Балтиморі (1975) та Нью-Йорку (1980); у 1991 р. ще раз вийшла друком у видавництві «Либідь», 1994 р. - у Видавничому домі «КМ Academia», 1997 р. - у видавництві ім. Олени Теліги)»** [8, с. 39]. У книжці зібрано тільки ті помилки, що «трапляються більш-менш часто, притаманні багатьом, і тим самим знижують загальний рівень нашої мовної культури» [5, с. 240]. Порадник складається 3 дванадцяти 
розділів, кожний із яких присвячено розглядові окремої частини мови*** (на початку книжки автор розглядає самостійні частини мови, потім службові, а в кінці приділено увагу вигукові). Розділи, де розглядаються самостійні частини мови, побудовано за однією структурою: спочатку автор подає типові помилки, пов'язані 3 уживанням певної частини мови, далі пропонує правильний варіант із теоретичним обгрунтуванням своєї думки, або пропозиції (ілюструючи його численними прикладами 3 мови письменниківкласиків та «живої» народної мови), а наприкінці висловлює свої зауваженнями щодо правильності вживання тих мовних одиниць, яким присвячено розділ. Наприклад, розділ «Іменник» починається з прикладів неправильного відмінювання іменників, а також порушення правил уживання іменників у роді й числі. Дослідник надає нормативні варіанти 3 докладним поясненням та відповідним ілюстративним матеріалом. Закінчується розділ «Зауваженнями до окремих іменників», де автор розглядає випадки вживання того чи того іменника в конкретній мовній ситуації. Наприклад: чи існує різниця між іменниками «книга» і «книжка», «площуа» і «майдан»; чи можна вважати абсолютними синонімами іменники «вираз» і «вислів» і т. ін. Чотири окремі розділи, де розглядаються службові частини мови та вигук, не мають авторських «Зауважень ...» (у кожному 3 цих розділів Б. Антоненко-Давидович розглядає конкретні випадки вживання чи то прийменника, чи то частки, чи то сполучника, чи то вигука). На особливу увагу заслуговує той факт, що авторські думки, висловлені в книжці «Як ми говоримо» щодо нормативності вживання тієї чи тієї мовної одиниці або синтаксичної конструкції, у значній мірі збігаються з рекомендаціями та порадами мовознавців 20-х років XX ст., що дозволяє говорити про очевидний вплив тогочасних нормалізаторів української літературної мови (О. Курило, О. Синявський, М. Сулима, М. Гладкий, В. Сімович, C. Смеречинський та ін.) на мовознавчі погляди Б. АнтоненкаДавидовича.

Іще цей вплив виявився й у застосуванні автором наукових критеріїв нормативності при визначенні правильності, або зразковості, тієї чи тієї мовної форми. Як зазначив Б. Антоненко-Давидович, «усі позитивні приклади-ілюстрації» на підтвердження своєї думки, або пропозиції, він свідомо добирав із таких джерел: 1) «твори класиків української літератури, починаючи від І. Котляревського»; 2) «живе народне мовлення, почуте з уст»; 3) авторитетні словники; 4) »твори сучасних українських... письменників М. Бажана, О. Гончара, 
М. Стельмаха та інших» [7, с. 241].

Перше видання мовного порадника вийшло 3 переднім словом I. Варченка, який зазначив, що «здебільша вона [книжка «Як ми говоримо»] складається 3 незаперечних, слушних, значущих і повчальних спостережень ...» [9, с. 7-8]. За словами Д. Чуба, книжка Б. Антоненка-Давидовича, «це надзвичайно цінна праця про красу української мови, як оберігати іiі від засмічення непотрібними русизмами та невірними виразами, словами-покручами» [35, с. 30]. Б. Тимошенко також високо поцінував названу працю письменника, акцентувавши увагу читачів на тому, що сьогодні «дуже актуальними $є$ лінгвістичні праці, які допомагають нашій мові набути первозданного, здорового вигляду», і саме до таких праць він зарахував порадник Б. Антоненка-Давидовича «Як ми говоримо» [33, с. 5].

Отже, проаналізований матеріал дає підстави зробити такі висновки: 1) мовознавчі розвідки Б. Антоненка-Давидовича, особливо його праця «Як ми говоримо», виявилися під ту пору (60-ті - 70-ті рр. ХХ ст.) вкрай актуальними й потрібними для тих культурних верств населення, яким була небайдужа доля української мови загалом i проблеми мовної культури зокрема (перевидання його мовного порадника через сорок років після першої публікації засвідчує актуальність книжки і для сучасного українського мовця); 2) на формування мовознавчих поглядів Б. Антоненка-Давидовича вплинули рекомендації та приписи нормалізаторів 20-х років XX ст., що засвідчують його праці з культури української мови (особливо його порадник «Як ми говоримо»); 3) письменник на особистому прикладі довів, що добре знати рідну мову може кожний свідомий громадянин своєї країни, незалежно від свого походження, рівня освіти, мовного оточення, професії і т. ін. Головне - це бажання все життя вчитися рідної мови 3 класичної літератури, авторитетних лексикографічних праць і народних джерел.

\section{Примітки}

*Убачаємо в цьому вплив мовознавців 20-х років ХХ ст. (О. Курило, М. Сулима, О. Синявський, М. Гладкий та ін.), які при внормуванні того чи того мовного явища послуговувалися такими основними критеріями: 1) етнографічний; 2) поширеність мовного явища в мовній практиці письменників-класиків; 3) історичний або традиційний [див.: 20, с. III; 29, с. 137; 12, с. 70-71; 13, с. 40].

**Додаймо, що в 2010 році в київському видавництві «Книга» вийшло п’яте, перероблене й доповнене, видання порадника «Як ми говоримо» зі вступним словом Б. Тимошенка [33].

***Таким формам дієслова, як дієприкметник і дієприслівник, автор порадника присвятив два окремі розділи [див.: 5, с. 184-197, 198-200]. 


\section{Література}

1. Антоненко-Давидович Б. Краса рідної мови / Б. Антоненко-Давидович // В літературі й коло літератури. - К. : Молодь, 1964. - С. 227-238.

2. Антоненко-Давидович Б. На сторожі слова. Замітки про мову творів молодих прозаїків / Б. Антоненко-Давидович // Про що і як. В літературі й коло літератури. К. : Радянський письменник, 1962. - С. 98-127.

3. Антоненко-Давидович Б. Про те ж саме. Мова літератури для дітей / Б. Антоненко-Давидович // В літературі і коло літератури. - К. : Молодь, 1964.C. $193-226$.

4. Антоненко-Давидович Б. Тонни і грам / Б. Антоненко-Давидович // В літературі й коло літератури. - К. : Молодь, 1964. - С. 164-192.

5. Антоненко-Давидович Б. Як ми говоримо / Б. Антоненко-Давидович. К. : Радянський письменник, 1970. -253 с.

6. Божко О. Лексико-семантичне поле «людина» в мові прозових творів Б. АнтоненкаДавидовича / О. Божко // Лінгвістика : [зб. наук. праць]. - Луганськ, 2006. - № 4 (10). C. 243-250.

7. Божук О. Епітет український у прозі Б. Антоненка-Давидовича 20-30-х років ХХ століття / О. Божук // Культура слова. - 2002. - Вип. 61. - С. 24-27.

8. Бойко Л. 3 когорти одержимих / Л. Бойко // Б. Д. Антоненко-Давидович. Твори в 2 т. / [вступ. ст., упорядкув. та прим. Л. С. Бойка]. - К. : Наукова думка, 1999. - Т. 1: Повісті та романи. - С. 5-46.

9. Варченко І. Книжка захоплива, збудлива, заклична / І. Варченко // Б. АнтоненкоДавидович. Як ми говоримо. - К. : Радянський письменник, 1970. - С. 3-10.

10. Вишневська Г. Питання української мови у творчій спадщині Б. АнтоненкаДавидовича / Г. Вишневська // Українська мова в процесі національно-культурного відродження України : [зб. наук. праць]. - К., 1993. - С. 28-30.

11. Гладкий М. Синтакса нашої газетної мови / М. Гладкий // Червона преса. - 1927. № 8-9. - С. 59-63.

12. Гладкий М. Стабілізація української мови / М. Гладкий // Життя й революція. 1927. - № 4. - С. 70-78.

13. Гладкий М. Фразеологія газетної мови / М. Гладкий // Червона преса. - 1928. № 1. - C. 39-43.

14. Карчевська О. Розмовні та книжні фразеологічні одиниці у прозових текстах Б. Антоненка-Давидовича / О. Карчевська // Культура слова. - 2006. - Вип. 66-67. C. $36-42$.

15. Касян Л. «Дати поштовх до роздуму, до дбайливого поводження зі своєю мовою, а значить - i до самовдосконалення в ній ...» (Праця Бориса Антоненка-Давидовича «Як ми говоримо» в процесі унормування української літературної мови) / Л. Касян // Українознавство. - 2009. - № 4. - С. 212-216.

16. Касян Л. Мовна особистість Бориса Антоненка-Давидовича в українознавчому вимірі / Л. Касян // Українознавство. - 2007. - № 2. - С. 196-200.

17. Касян Л. Мовознавчі праці Бориса Антоненка-Давидовича у контексті культурно-громадського життя 50-80 років XX ст. / Л. Касян // Наука і сучасність : [зб. наук. праць]. - К. : Вид-во НПУ ім. Драгоманова, 2007. - Т. 59. - С. 196-203.

18. Касян Л. «Чому ж, друзі, вас так мало?»: Екстра- та інтралінгвальні фактори формування Б. Антоненка-Давидовича як мовної особистості/ Л. Касян // Урок української. - 2008. - № 3/4. - С. 19-23. 
19. Костюк Г. ...Що вгору йде... / Г. Костюк // Сучасність: Література, мистецтво, суспільне життя. - Мюнхен: Вид. Українське товариство закордонних студій «Сучасність», 1980. - Ч. 10 (238). - С. 32-46.

20. Курило О. Від редакції / О. Курило // Збірник секції граматики української мови / [ред. : О. Курило]. - К., 1930. - Кн. перша. - С. III-V.

21. Курило О. Уваги до сучасної української літературної мови / О. Курило. - К., 1920. - 47 c.

22. Курило О. Уваги до сучасної української літературної мови / О. Курило. - [3-тє вид.]. - К. : Книгоспілка, 1925. - 248 с.

23. Масенко Л. Мовна політика в УРСР: історія лінгвоциту / Л. Масенко // Українська мова у XX сторіччі: історія лінгвоциду [док. і матеріали] / [упоряд.: Л. Масенко та ін.]. - К. : ВД «Києво-Могилянська акад.», 2005. - С. 5-36.

24. Перегінець М. Словотвір. Лекція VII / М. Перегінець // Загальний курс української мови / [за ред. Л. А. Булаховського ]. - [2-ге вид.]. - Х., 1931. - С. 121-141.

25. Синявський О. Норми української літературної мови / О. Синявський. - Х.; К. : Література й мистецтво, 1931. - 368 с.

26. Сімович В. Граматика української мови для самонавчання в допомогу шкільній науці / В. Сімович. - [2-е вид.]. - К. ; Ляйпціг, 1919. - 584 с.

27. Сімович В. На теми мови / В. Сімович. - Прага; Берлін : Нова Україна, 1924. - 45 с.

28. Смеречинський С. Нариси з української синтакси (у зв'язку з фразеологією та стилістикою) / С. Смеречинський. - Х. : Радянська школа, 1932. - 283 с.

29. Сулима М. Проблема літературної норми в українській мові / М. Сулима // Шлях освіти. - 1928. - № 4. - С. 132-141.

30. Сулима М. Регулятори й дисонатори української літературної мови / М. Сулима // Життя й революція. - 1927. - № 1. - С. 74-78.

31. Сулима М. Українська фраза. Коротенькі начерки / М. Сулима. - Х. : Рух, 1928. - 96 c.

32. Сулима М. Фразеологія Миколи Хвильового (фрагменти) / М. Сулима // Червоний шлях. - 1925. - № 1-2. - С. 263-290.

33. Тимошенко Б. Подих кожного слова / Б. Тимошенко // Б. АнтоненкоДавидович. Як ми говоримо. - К.: ВД «КМ Academia», 1994. - [4-е вид., перероб. і доп.]. - С. 3-11.

34. Хамедова О. А. Б. Антоненко-Давидович : доля, творчість, критична рецепція : автореф. дис. ... канд. філол. наук : спец. 10.01.01 «Українська література». - Х., 2008. - 20 c.

35. Чуб Д. Борис Антоненко-Давидович (80 років 3 дня народження) / Д. Чуб // Б. Антоненко-Давидович. Печатка. - Мельборн: Ластівка, 1979. - С. 7-30.

Стаття надійшла до редакції 08.06.2012 р. 